\title{
Biospeckle Laser Technique for mechanical damage assessment in Tommy atkins mango fruits
}

\author{
Técnica Biospeckle Laser para avaliação de danos mecânicos \\ em mangas Tommy
}

Taize Calvacante Santana ${ }^{1 *}$ (D), Rodes Angelo Batista da Silva ${ }^{1}$ (D), Héliton Pandorfi ${ }^{1}$ (i), Marcos Vinícius da Silva ${ }^{1}$ (D), Silvestre Rodrigues ${ }^{2}$ (D), Cristiane Guiselini ${ }^{1}$ (i),

Sávio Duarte Lopes Cavalcanti ${ }^{1}$ (D), Nicoly Farias Gomes ${ }^{1}$ (i)

${ }^{1}$ Universidade Federal Rural de Pernambuco (UFRPE), Departamento de Engenharia Agrícola, Recife/PE - Brasil

2Universidade Federal de São João Del Rei (UFSJ), Departamento de Ciências Agrárias, São João Del Rei/MG, Brasil

*Corresponding Author: Taize Calvacante Santana, Universidade Federal Rural de Pernambuco (UFRPE),

Departamento de Engenharia Agrícola, Rua Manuel de Medeiros, s/n, CEP: 52171-900, Recife/PE - Brasil, e-mail: taizehaes@gmail.com

Cite as: Santana, T. C., Silva, R. A. B., Pandorfi, H., Silva, M. V., Rodrigues, S., Guiselini, C., Cavalcanti, S. D. L., \& Gomes, N. F. (2021). Biospeckle Laser Technique for mechanical damage assessment in Tommy atkins mango fruits. Brazilian Journal of Food Technology, 24, e2020198. https://doi.org/10.1590/1981-6723.19820

\begin{abstract}
The objective of this study was to evaluate the response of biological activity measured by the Biospeckle Laser technique applied to mangoes (Mangifera indica L.) subjected to mechanical damage at different stages of maturation. The tests were carried out twice a week for twenty-one days, and 40 mangoes of the variety Tommy Atkins were used. The procedure was divided into two stages: the first simulated the impact on fruits, and in the second stage, the laser light was applied to the impacted area. After laser application, the images of all fruits were submitted to graphic processing, in order to obtain maps of biological activity of the fruits. The Biospeckle laser technique associated with image analysis allowed the identification of distinct biological activity levels in the mangoes, certifying its potential application as a non-destructive test tool, in the monitoring of biological activity in fruit samples.
\end{abstract}

Keywords: Non-destructive analysis; Bioactivity; Mechanical damage; Optics; Programming; Quality.

\section{Resumo}

Objetivou-se avaliar a resposta da atividade biológica medida pela técnica Biospeckle Laser aplicada a mangas (Mangifera indica L.) submetidas a danos mecânicos, em diferentes estágios de maturação. Os testes foram realizados duas vezes por semana, durante 21 dias, sendo utilizados 40 frutos de manga da variedade Tommy. 0 procedimento foi dividido em duas etapas: na primeira etapa, simulou-se o impacto nos frutos; na segunda etapa, foi aplicada a luz laser sobre a área que sofreu impacto, seguido do registro das imagens de todos os frutos. Esses registros foram submetidos a um processamento gráfico, com a finalidade de se obterem mapas de atividade biológica dos frutos. A técnica Biospeckle laser associada à análise de imagem permitiu identificar níveis de 
atividades biológicas distintas nas mangas, certificando o seu potencial de aplicação como ferramenta de teste não destrutivo, no monitoramento da atividade biológica em amostras de frutos.

Palavras-chave: Análise não destrutiva; Bioatividade; Danos mecânicos; Ótica; Programação; Qualidade.

\section{Introduction}

The Biospeckle Laser (BL) technique is based on the optical interference phenomenon that occurs when a coherent beam of light strikes a dynamic surface or a biological material (Rabal \& Braga Júnior, 2008; Braga Júnior, 2017; Rivera et al., 2019).

This technique has been used to monitor biological activity in fruits and vegetables (Ansari et al., 2012; Zdunek et al., 2014), to evaluate corn seed quality (Silva et al., 2018), coffee seed quality (Vivas et al., 2017), tomato ripening (Pieczywek et al., 2018), among others.

The physical and mechanical damage are among the elements of great relevance for fruit analysis (Vélez Rivera et al., 2014). They can be a result from impact during management, insect attacks, among others, which usually cause areas with reduced biological activity (Zhang et al., 2018).

Damage analyses by images have shown great potential in the evaluation of biological material characteristics (Vivas et al., 2017). Computational image analysis methods have gained popularity in recent years in various areas of science, including fruit biology (Ansari \& Nirala, 2014; Samuel et al., 2017; Salambue et al., 2018).

The identification and mapping of the phenomena resulting from biological activity becomes viable through the use of frequency analysis techniques such as the Wavelet Transform, which allows the use of long intervals of time to find low frequency information, and short intervals of time. time to find high frequency information (Misiti, 2005). High-frequency information is widely used to isolate the frequency at which certain phenomena act on the material, such as respiration, oxidation, water activity, among other metabolic processes (Cardoso et al., 2011).

Results from BL image processing are generally presented in graphical form (Minz \& Nirala, 2014; Stoykova et al., 2015; Braga Júnior et al., 2016). Analyzes are performed using a long offline approach, which is initiated only after image acquisition is completed (Rivera et al., 2019).

Among the many image processing methods, the generalized differences method (GD) has good qualitative results (Kumari \& Nirala, 2016). The GD algorithm calculates the absolute sum of the intensity differences between an image and its subsequent one, identifying the luminous intensity of each component pixel, thus resulting in a new image, which the pixels with different intensities highlighted (Minz \& Nirala, 2013).

The insertion of these techniques in the processing of images from BL enables the identification and the generation of maps, which allows the identification of areas with distinct activities in fruits, granting the localization of phenomena that may compromise their quality.

In this context, this study aimed to evaluate the response of biological activity measured by the Biospeckle Laser technique applied to mangoes (Mangifera indica L.) subjected to mechanical damage at different maturation stages.

\section{Material and methods}

Fruit analyzes were performed at the Federal University of Sergipe - UFS, in the municipality of São Cristóvão, located in Sergipe State (Figure 1). Forty mango fruits of the cultivar Tommy Atkins (Mangifera indica L.) were harvested at the early stage of ripening from a farm located in Neópolis city, Sergipe State, 
at latitude $10^{\circ} 19^{\prime} 16^{\prime} \mathrm{S}$, longitude $36^{\circ} 35^{\prime} 34^{\prime \prime} \mathrm{W}$ and altitude of $63 \mathrm{~m}$. The climate of the region is characterized as As - a tropical climate with dry season, according to the Köppen-Geiger classification (Peel et al., 2007).

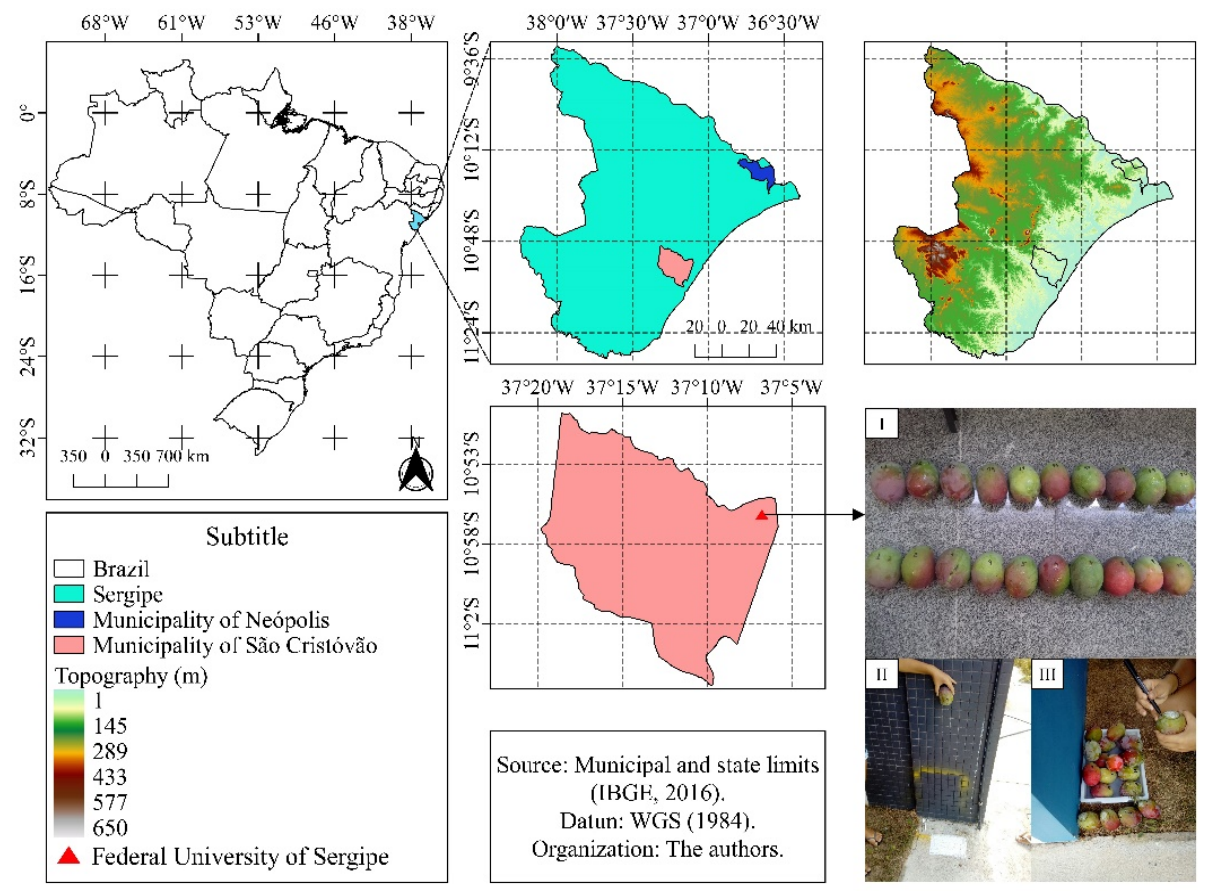

Figure 1. Location of fruit collection and performance of the experimental tests. Randomly selected Tommy Atkins mango fruits (I); paved surface covered with chalk dust (II); delimitation of the area marked by impact chalk dust (III).

The HeNe laser, with $632 \mathrm{~nm}$ wavelength and $10 \mathrm{~mW}$, was positioned at a height of $15 \mathrm{~cm}$ above the sample. The fruit images were recorded by a SONY DCR-SX21 digital camera with $640 \times 480$ pixels resolution focal length $\mathrm{f}=1.8 \mathrm{~mm}$ to $102.6 \mathrm{~mm}$ and aperture F1.8-F5.7, equipped with expansion lens and coupled to a computer equipped with Matlab and ImageJ software, for data analysis. Initially, the twenty selected random fruits went through the damage process (Figure 1-I), and the other twenty served as control and were not damaged.

The fruit damage process consisted of a free fall of $1 \mathrm{~m}$ in height, over a paved (concrete) surface covered with chalk dust, which marked the contact area between the fruit and the paved surface (Figure 1-II). The area marked on the fruit by chalk powder was then delimited (Figure 1-III), and subsequently submitted to the Biospeckle Laser technique. The graphic processing of the results was done by Matlab software, according to the generalized difference methodology (GD), which allowed the obtention of visual maps from the damaged area (Minz \& Nirala, 2013), which uses Equation 1.

$D G_{(i j)}=\sum_{K} \sum_{I}\left|I_{K}(i, j)-I_{k}+I(i, j)\right|$

where,

$\mathrm{K}$ - number of images;

I - pixel intensity;

ij - subsequent pixels.

The tests were performed twice a week, for three weeks, with a total of five tests in the same fruits. In each evaluation, a video of each fruit was recorded and converted into frame-by-frame images of the impacted area,which was used to perform the graphic processing of the images (Figure 2A). The experimental setup scheme is shown in Figure 2B. 


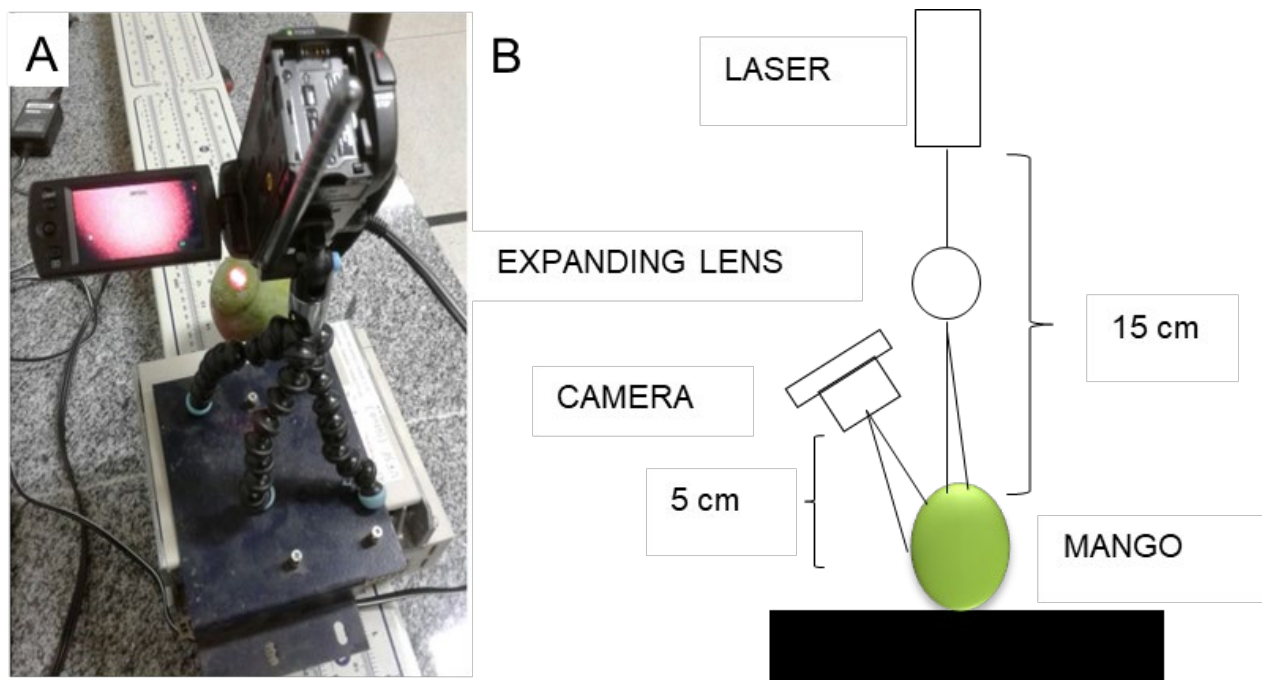

Figure 2. Biospeckle observation (A); experimental setup scheme (B).

Both damaged and control fruits underwent laser illumination in order to monitor the levels of biological activity in the impacted region (Figure 2A). When an object is illuminated by the laser, an interference figure is formed due to the scattering caused by the physical constitution of the object's matter.

For each fruit, 128 images regarding the Biospeckle standards were used. They had $640 \times 480$ pixels, were acquired at a rate of $0.067 \mathrm{~s}$ and were in the frequency range of 0 to $7.5 \mathrm{~Hz}$ in 8 -bit format. The results were obtained in 25 frequency bands. The number of frequency bands is related to the number of images, and for a set of 128 and 64 images, there is a total of 25 and 21 frequency bands, respectively.

The 25 bands generated refer to the distinct frequencies that were decomposed by the Wavelets transform, which has the ability to open the signal in various frequencies that compose it in relation to the time domain, thus allowing its reconstruction entirely, or without the frequency bands to be filtered, therefore facilitating the understanding, transmission and analysis of many images. This technique is the basis of a powerful new approach to signal processing and analysis (Gonzalez \& Woods, 2010).

Image reconstruction was performed by removing one band at a time for the signal provided by each pixel of the images.

Then, by means of the generalized differences method (GD), the reference images were generated. These images are also called bioactivity maps, and are shown in gray scale with the representation of different biological activities in the fruits, in order to allow better visualization of the different activity levels contrast; after that, a RGB filter was applied using the Image J software.

The bioactivity maps generated by the GD technique were subjected to further analysis, in order to isolate the higher intensity pixels from the reflection generated by the laser interaction with the material exhibiting activity. The images were classified from all the pixels that compose them (black, blue, green and yellow), through a color scale in pixels that relates the color to a bioactivity band, in which the green pixels are considered as the of greater biological activity and the blue ones as those with less activity in the fruits.

\section{Results and discussion}

Figure 3 shows the processed images for the control and the impacted mangoes, from the first to the fifth test. 


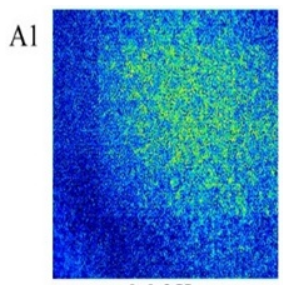

$0-0,3 \mathrm{~Hz}$

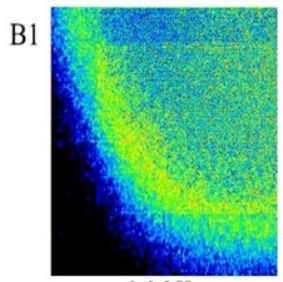

$0-0,3 \mathrm{~Hz}$

$\mathrm{C} 1$

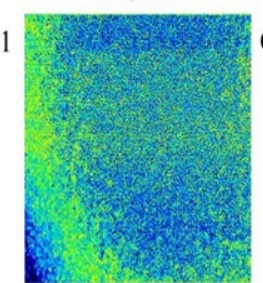

$0-0,3 \mathrm{~Hz}$

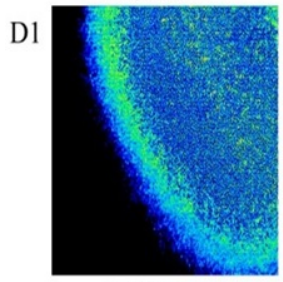

$0-0,3 \mathrm{~Hz}$

El

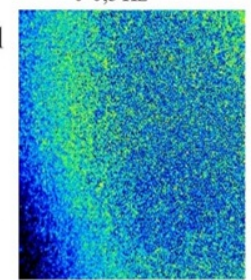

$0-0.3 \mathrm{~Hz}$

F1

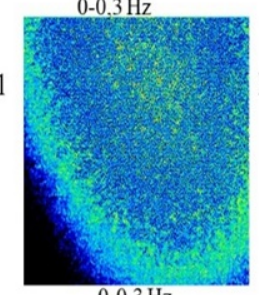

$0-0,3 \mathrm{~Hz}$

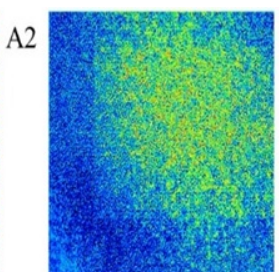

$0,3-0,6 \mathrm{~Hz}$

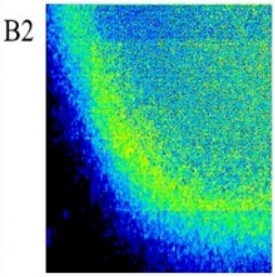

$0,3-0,6 \mathrm{~Hz}$

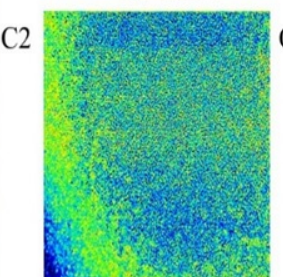

$0,3-0,6 \mathrm{~Hz}$

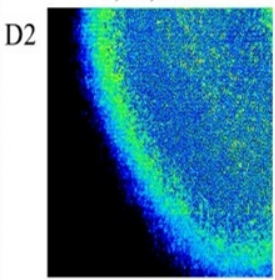

$0,3-0,6 \mathrm{~Hz}$

E2

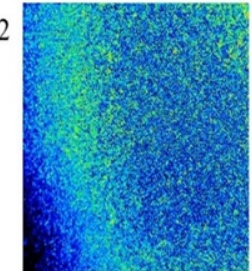

$0.3-0.6 \mathrm{~Hz}$

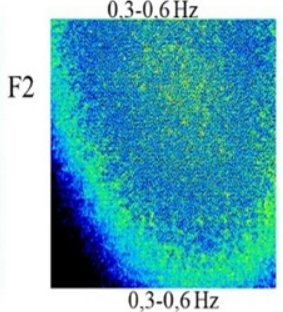

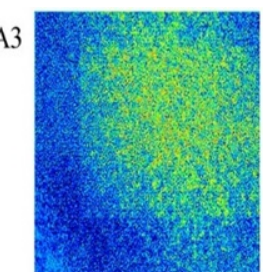

$0,6-0,9 \mathrm{~Hz}$

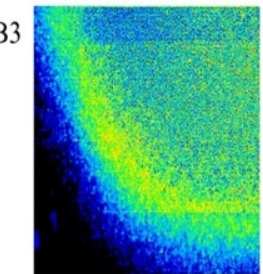

$0,6-0,9 \mathrm{~Hz}$

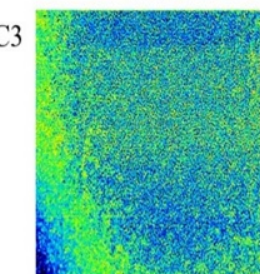

$0,6-0,9 \mathrm{~Hz}$

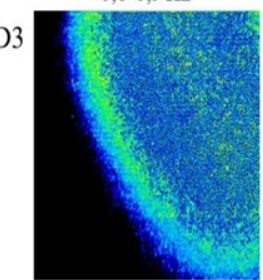

$0,6-0,9 \mathrm{~Hz}$

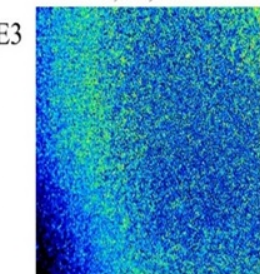

$0.6-0.9 \mathrm{~Hz}$

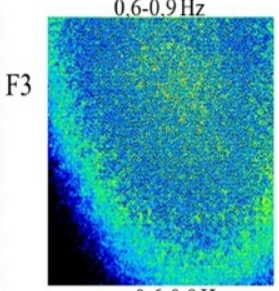

$0,6-0,9 \mathrm{~Hz}$

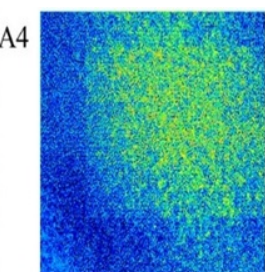

$0,9-1,2 \mathrm{~Hz}$

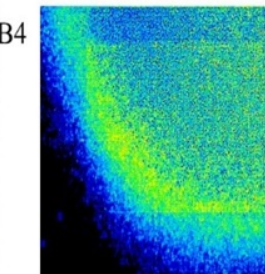

$0,9-1,2 \mathrm{~Hz}$

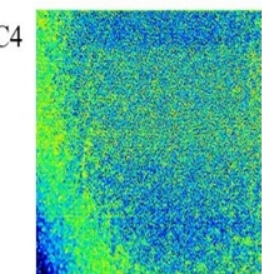

$0,9-1,2 \mathrm{~Hz}$

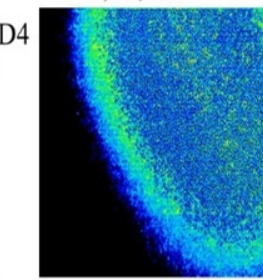

$0,9-1,2 \mathrm{~Hz}$

E4

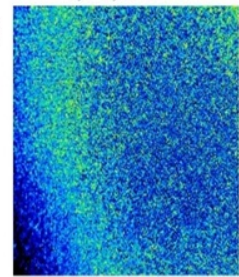

$0.9-1.2 \mathrm{~Hz}$

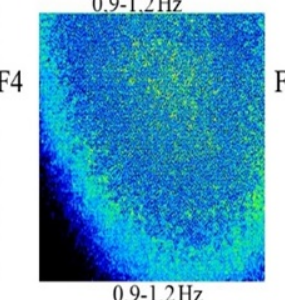

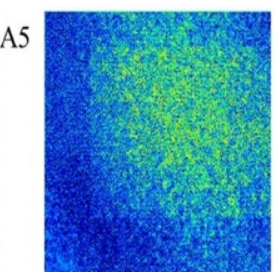

$1,2-1,5 \mathrm{~Hz}$

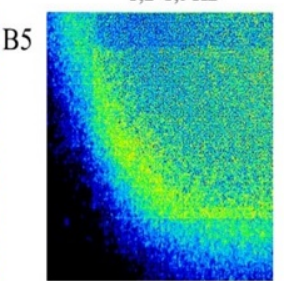

$1,2-1,5 \mathrm{~Hz}$

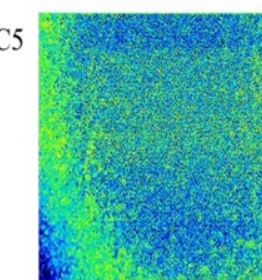

$1,2-1,5 \mathrm{~Hz}$

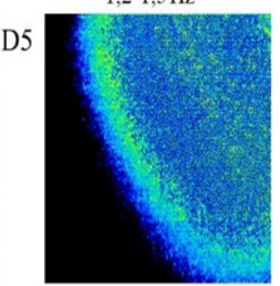

$1,2-1,5 \mathrm{~Hz}$

E5

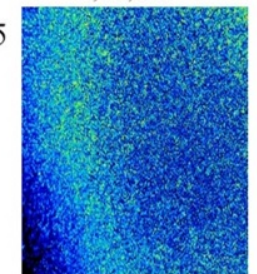

$1.2-1.5 \mathrm{~Hz}$

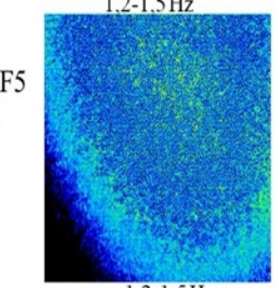

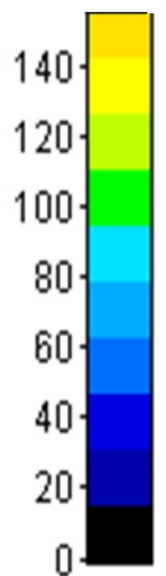

Figure 3. Bioactivity for the control mangoes (A1, A2, A3, A4 and A5), first test (B1, B2, B3, B4 and B5), second test (C1, C2, C3, C4 and C5), third test (D1, D2, D3, D4 and D5), fourth test (E1, E2, E3, E4 and E5) and fifth test (F1, F2, F3, F4 and F5).

The maps analysis was performed by the intensity of the pixels that compose them, where the regions with darker color (blue) represent a lower intensity of biological activity, and the regions with lighter color (yellow) represent greater intensity of biological activity (Figure 3).

The maps of fruits subjected to impact (Figure 3B1-3F5) and the control ones (Figure 3A1-3A5) showed changes in the activity pattern from the first to the fifth test. The Wavelets transform showed the presence of 
low and high frequency pixels in the Biospeckle signal, both for the impacted and for the control mangoes, which characterizes different levels of biological activity (Rivera \& Braga Júnior, 2017).

Alves et al. (2013) used the Biospeckle laser technique to identify physiological changes in minimally processed carrots, and they concluded that it is possible to identify different activity levels, and to evaluate, in a non-destructive way, the expression of water activity and respiratory rate separately. These measurements of biological activity during fruit development are the result of physicochemical variations that occur inside the cells, and such behavior of biological activity reduction may be caused by metabolic, enzymatic and respiratory activity that occur during the ripening process.

Kumari \& Nirala (2016) used the Biospeckle laser to differentiate fresh from damaged areas in apples. They found that the level of biological activity in both areas decreased as the maturation process evolved, which corroborates the results found in our paper.

Braga et al. (2009) evaluated the ability of the Biospeckle laser technique and generalized differences to detect changes in the biological activity of the root tissues of Coffea arabica and Eucalyptus grandis plants. The results were satisfactory and point to the Biospeckle technique as a potential indicator of biological activity measurement in root tissues.

In corroboration with our study, several studies using the Biospeckle laser technique as an indicator of biological activity associated with plant quality and senescence can be found in the literature, with satisfactory results. Studies such as Rabelo et al. (2005) satisfactorily quantified the biological activity by Biospeckle to indicate the orange quality during post-harvest fruit senescence. Santana et al. (2018) the identified mechanical damage generated on corn grains during harvesting, highlighting the site of damage development and the consequent loss of activity, which allowed us to infer that the Biospeckle laser technique is effective in identifying mechanical damage.

The absorption of laser light by the plant tissue during illumination caused by the Biospeckle technique has a direct relationship with the chemical components of the fruit, such as pigments, water and sugar (Williams \& Norris, 2001). Mechanical damages in fresh fruits cause the rupture of the pressed tissues at a microscopic level, a factor that favors their darkening due to the oxidation of phenolic compounds, resulting in loss of product quality (Enes et al., 2012; Pandiselvam et al., 2020). Thus, the reduction in biological activity measured by the Biosepckle laser is based on the deterioration of fruits in an advanced state of maturity and the consequent alteration of their chemical components, as well as their metabolic activity, in which the damaged tissues have reduced biological activity (Samuel et al., 2016).

\section{Conclusions}

The Biospeckle laser technique associated with image analysis allowed the identification of distinct biological activity levels, both in the impacted and control mangoes, thus demonstrating its application potential as a non-destructive testing tool to monitor fruit's activity.

\section{References}

Alves, J. A., Braga Júnior, R. A., \& Vilas Boas, E. V. B. (2013). Identification of respiration rate and water activity change in fresh-cut carrots using biospeckle laser and frequency approach. Postharvest Biology and Technology, 86, 381-386. http://dx.doi.org/10.1016/j.postharvbio.2013.07.030

Ansari, Z., Minz, P. D., \& Nirala, A. K. (2012). Fruit quality evaluation using biospeckle techniques. In $1^{\text {st }}$ International Conference on Recent Advances in Information Technology (RAIT) (pp. 873-876). New York: IEEE. http://dx.doi.org/10.1109/RAIT.2012.6194540.

Braga Júnior, R. A. (2017). When noise became information: State-of-the-art in biospeckle laser. Ciência e Agrotecnologia, 41(4), 359-366. http://dx.doi.org/10.1590/1413-70542017414000317

Braga Júnior, R. A., Rivera, F. P., \& Moreira, J. (2016). A practical guide to biospeckle laser analysis: Theory and software. Lavras: Editora UFLA. Retrieved in 2019, April 20, from http://repositorio.ufla.br/jspui/handle/1/12119 
Braga, R. A., Dupuy, L., Pasqual, M., \& Cardoso, R. R. (2009). Live biospeckle laser imaging of root tissues. European Biophysics Journal, 38(5), 679-686. PMid:19266191. http://dx.doi.org/10.1007/s00249-009-0426-0

Cardoso, R. R., Costa, A. G., Nobre, C. M. B., \& Braga Junior, R. A. (2011). Frequency signature of water activity by biospeckle laser. Optics Communications, 284(8), 2131-2136. http://dx.doi.org/10.1016/j.optcom.2011.01.003

Enes, A. M., Fracarolli, J. A., Dal Fabbro, I. M., \& Rodrigues, S. (2012). Biospeckle supported fruit bruise detection. International Journal of Nutrition and Food Engineering, 6(10), 889-891. http://dx.doi.org/10.5281/zenodo.1080072

Gonzalez, R. C., \& Woods, R. C. (2010). Processamento digital de imagens (3. ed.). São Paulo: Pearson Prentice Hall.

Kumari, S., \& Nirala, A. K. (2016). Biospeckle technique for the non-destructive differentiation of bruised and fresh regions of an Indian apple using intensity-based algorithms. Laser Physics, 26(11), 115601. http://dx.doi.org/10.1088/1054-

$660 X / 26 / 11 / 115601$

Minz, P. D., \& Nirala, A. K. (2013). Assessment of bio-activity of the fruits using intensitybased methods. In 2013 International Conference on Microwave and Photonics (ICMAP) (pp. 1-4). New York: IEEE. https://doi.org/10.1016/j.ijleo.2014.01.083.

Minz, P. D., \& Nirala, A. K. (2014). Intensity based algorithms for biospeckle analysis. Optik, 125(14), 3633-3636.

http://dx.doi.org/10.1016/j.ijleo.2014.01.083

Misiti, M. (2005). Wavelet toolbox for use Matlab: User guide. Version 3 (625 p.). Natick: The MathWorks.

Pandiselvam, R., Mayookha, V. P., Kothakota, A., Ramesh, S. V., Thirumdas, R., \& Juvvi, P. (2020). Biospeckle laser technique: A novel non-destructive approach for food quality and safety detection. Trends in Food Science \& Technology, 97, 113. http://dx.doi.org/10.1016/j.tifs.2019.12.028

Peel, M. C., Finlayson, B. L., \& Mcmahon, T. A. (2007). Updated world map of the Köppen-Geiger climate classification. Hydrology and Earth System Sciences Discussions, 4(2), 439-473.

Pieczywek, P., Nowacka, M., Dadan, M., Wiktor, A., Rybak, K., Witrowa-Rajchert, D., \& Zdunek, A. (2018). Postharvest monitoring of tomato ripening using the dynamic laser speckle. Sensors, 18(4), 1093. PMid:29617343. http://dx.doi.org/10.3390/s18041093

Rabal, H. J., \& Braga Júnior, R. A. (2008). Dynamic laser speckle and applications. Boca Raton: CRC Press. http://dx.doi.org/10.1201/9781420060164.

Rabelo, G. F., Braga Júnior, R. A., \& Fabbro, I. M. D. (2005). Laser speckle techniques in quality evaluation of orange fruits. Revista Brasileira de Engenharia Agrícola e Ambiental, 9(4), 570-575. http://dx.doi.org/10.1590/S1415-43662005000400021

Rivera, F. P., \& Braga Júnior, R. A. (2017). Selection of statistical indices in the biospeckle laser analysis regarding filtering actions. Optics Communications, 394, 144-151. http://dx.doi.org/10.1016/j.optcom.2017.03.015

Rivera, F. P., Braga Júnior, R. A., lannetta, P., \& Toorop, P. (2019). Sound as a qualitative index of speckle laser to monitor biological systems. Computers and Electronics in Agriculture, 158, 271-277. http://dx.doi.org/10.1016/j.compag.2019.01.051

Salambue, R., Adnan, A., \& Shiddiq, M. (2018). Investigation of the ripeness of oil palm fresh fruit bunches using bio-speckle imaging. Journal of Physics: Conference Series, 978, 012071. http://dx.doi.org/10.1088/1742-6596/978/1/012071

Samuel, B., Retheesh, R., Ansari, M. Z., Nampoori, V. P. N., Radhakrishnan, P., \& Mujeeb, A. (2017). Cross-correlation and time history analysis of laser dynamic specklegram imaging for quality evaluation and assessment of certain seasonal fruits and vegetables. Laser Physics, 27(10), 105601. http://dx.doi.org/10.1088/1555-6611/aa8283

Samuel, B., Retheesh, R., Nampoori, V. P. N., \& Mujeeb, A. (2016). Nondestructive evaluation of fruits using cross correlation and time history of biospeckle pattern. In Indian National Seminar \& Exhibition on Non-Destructive Evaluation NDE 2016 (pp. 470-473). India: NDT.

Santana, T. C., Rodrigues, S., Enes, A. M., Nogueira, C. F. M., \& Vale, G. W. (2018). Evaluation of losses in mechanical corn harvest under three speeds. International Journal of Science and Engineering Investigations, 7, 1-4. Retrieved in 2019, April 20, from http://www.ijsei.com/papers/ijsei-77518-01.pdf

Silva, G. M., Peixoto, L. S., Fujii, A. K., Parisi, J. J. D., Aguiar, R. H., \& Fracarolli, J. A. (2018). Evaluation of maize seeds treated with Trichodermil ${ }^{\circledR}$ through biospeckle. Journal of Agricultural Science and Technology, 8, 175-187. http://dx.doi.org/10.17265/2161-6264/2018.03.004

Stoykova, E., Nazarova, D., Berberova, N., \& Gotchev, A. (2015). Performance of intensity-based non-normalized pointwise algorithms in dynamic speckle analysis. Optics Express, 23(19), 25128-25142. PMid:26406712.

http://dx.doi.org/10.1364/OE.23.025128

Vélez Rivera, N., Gómez-Sanchis, J., Chanona-Pérez, J., Carrasco, J. J., Millán-Giraldo, M., Lorente, D., Cubero, S., \& Blasco, J. (2014). Early detection of mechanical damage in mango using NIR hyperspectral images and machine learning. Biosystems Engineering, 122, 91-98. http://dx.doi.org/10.1016/j.biosystemseng.2014.03.009

Vivas, P. G., Resende, L. S., Braga, R. A., Guimarães, R. M., Azevedo, R., da Silva, E. A. A., \& Toorop, P. E. (2017). Biospeckle activity in coffee seeds is associated non-destructively with seedling quality. Annals of Applied Biology, 170(2), 141149. http://dx.doi.org/10.1111/aab.12314

Williams, P., \& Norris, K. (2001). Near infrared technology in the agricultural and food industries (2nd ed., 237 p.). St. Paul: American Association of Cereal Chremist.

Ansari, M. Z., \& Nirala, A. K. (2014). Assessment of fruits during shelf-life storage using biospeckle laser. Agricultural Engineering International: CIGR Journal, 16(3), 223-229. Retrieved in 2019, April 20, from https://cigrjournal.org/index.php/Ejounral/article/view/2901/1955 
Zdunek, A., Adamiak, A., Pieczywek, P. M., \& Kurenda, A. (2014). The biospeckle method for the investigation of agricultural crops: A review. Optics and Lasers in Engineering, 52, 276-285. http://dx.doi.org/10.1016/j.optlaseng.2013.06.017

Zhang, B., Gu, B., Tian, G., Zhou, J., Huang, J., \& Xiong, Y. (2018). Challenges and solutions of optical-based nondestructive quality inspection for robotic fruit and vegetable grading systems: A technical review. Trends in Food Science \& Technology, 81, 213-231. http://dx.doi.org/10.1016/j.tifs.2018.09.018

Funding: None. 